\title{
Contents of Volume 6
}

Alföldi, I., Information technology at the Hungarian Central Statistical Office: Experience and plans

Boda, G., see B. Falussy

Bresnick, A., Networking, mainframes and local area networks at the Bureau of Labor Statistics

Cellerino, R., Environmental expenditure in Italian state and regional planning

Dravie, A., Attempting a patrimony account for land in Ivory Coast: Information system and agricultural development

Elvers, E., Quality presentation in environment statistics - some Swedish examples

Erritt, M.J., The organisation and management of statistical programmes in the United Kingdom

Falussy, B. and G. Boda, Changes in total worktime per unit of free time as a function of economic development

Fiebiger, H., On the methodology of time budget surveys in the GDR

George, M.V., see J. Perreault

Gewalli, L.E., Statistical data bank services in Denmark

Glaude, M. and M. Gombert, Household income by socio-occupational category

Gombert, M., see M. Glaude

Høie, H., see J.A. Vestøl

Hyland, W.J., Problems in classifying resources in educational statistics

Janhunen, O., Knowledge-based Statistical Systems - An Overview

Kallaste, T., An approach to forecast the level of air pollution

Keller, W.J. and K.J. Metz, The impact of new dataprocessing techniques at the Netherlands Central Bureau of Statistics 
Lindgren, A. and S. Johansson, The use of micro-computers at a statistical agency: A report on Statistics Sweden

Lützel, H., Household production and national accounts

Mata-Greenwood, A., Women in economic activity: Lessons from two surveys in Costa Rica and Kerala

Neumann, K. and J. Vogel, Design and implementation of computer-aided workplaces at the State Central Statistical Office of the German Democratic Republic

Perreault, J. and M.V. George, Methodological issues in the projection of households and families in Canada

Porras, J., International comparability of statistics of education

Sadovski, A.N., Experience with environment statistics in the Bulgarian environmental monitoring system

Stübler, W., A social account of international comparisons 359

Szilágyi, G., International demand analysis

Thygesen, L., Prospects for socio-demographic risk research in Denmark

Vestøl, J.A. and H. Høie, Sustainable agriculture: Assessments of agricultural pollution in the SIMJAR model 